\title{
Unravelling the Subject with Spinoza: Towards a morphological analysis of the scene of subjectivity
}

Caroline Williams School of Politics and International Relations, Queen Mary University of London, London E1 4NS, UK

\begin{abstract}
Whilst the concept of the subject has been called into question by many diverse approaches within contemporary political and social theory, there remains a focus upon agency, now attributable to reformulated subjectivities or assemblages. I query the persistence of this grammar of agency and ask whether politics can do without a scene of the subject. Spinoza's philosophy, in particular his conception of conatus, has inspired and offered some basis for rethinking agency; I examine two such prominent positions (Judith Butler and Jane Bennett) and argue that ultimately neither captures the political promise of Spinoza's philosophy. Configuring a concept of morphology to analyse this scene, my argument detaches the conatus from a narrow focus upon human desire, and focuses attention upon the scene of the subject as folded into a wider complex body. My approach also returns a study of power to the discussion: the conatus is the power to persist but it is also a differential force and site of conflict. By placing the spotlight on the scene of subjectivity in this way, the contemporary political theorist avoids the false antinomy between agency and structure, whilst continuing to track the production and composition of subjectivity in new political forms.
\end{abstract}

Keywords: morphology, Spinoza, conatus, scene of subjectivity, power, new materialism

The concept of the subject has been central to philosophical and political thought in the modern age where it has most often served the function of essential ground for metaphysical claims about knowledge and truth, or as a natural human foundation for thinking about the construction of the state and the terms and conditions of social contract. At the same time, and since its inception, this concept has also revealed itself to be neither stable nor self-contained. This has furnished a range of approaches, each calling into question its role in laying a foundation for philosophical thinking, and giving rise to a wide range of explorations seeking to reconfigure and sometimes displace the subject. Such theoretical manoeuvres have had inevitable political consequences, witnessed most clearly within structuralism, which for its many critics exposed an abiding tension between a form of anti-humanism, where the role for the agency and subjectivity was unwittingly dissolved, and an all-consuming concept of structure where lurked a dangerous supra-subjectivism (notably labelled by Paul Ricouer as a form of Kantianism without the transcendental subject); a tension eliciting the well-known political slogan of May 68: structures do not march on the streets! In practice, and with growing theoretical awareness, anti-humanists were concerned less with abolishing the 
subject and replacing it with a new foundation, and more with charting the subtle production of its multiple conditions of existence.

My intention is not to return directly to these now well-rehearsed debates, but to highlight a similar series of tensions, albeit with different inflections, that are strikingly evident in forms of contemporary critical thought. Here, a turn to Spinoza's philosophy has inspired and offered some basis for rethinking both the form or genesis of subjectivity, specifically its ethical comportment, and for unravelling the subject within a posthuman ontological setting. Paradoxically, these diverse turns to Spinoza have entailed attention be directed away from the subject and toward a foregrounding of processes of discursive or material production. Indeed, like earlier forms of antihumanism, these new positions hardly present a total eclipse of the modern grammar of subjectivity. The focus continues to be upon the agency of matter, objects or things, as well as a regard for human implication, and imbrication, within material and discursive processes. Not a surpassing of the human, then, but a recasting and recontextualising of its precise terms of reference (Wolfe, 2010; Braidotti, 2013). If the reverberations of a crisis of the subject of modern philosophy continue, efforts still abound in the theorisation of new conceptions of agency now attributable to reformulated, dispersed, or discursive subjectivities, or to non-subjective forms, fields, and assemblages. How might we understand this sustained interest in agency alongside what appears to be an elision of the metaphysical subject? We might want to inquire whether politics can do without this scene of the subject - even as it claims to reconceive its political forms and metaphysical status.

In this article I intend to respond to these problems by placing a spotlight precisely upon this scene of subjectivity. Inspired by my own engagement with Spinoza, I configure a conceptual tool, what I here call a morphology, to help investigate and map the ontological shape and force of this scene. This idea of morphology has two important dimensions that I briefly elucidate. Firstly, it is processual. It encourages a dynamic view of the unfinished formation of the subject, conceived as only one element or relation among a collection of many other bodies and things. A temporal series of potential relations might compose a morphology when various parts 'stick', conjoin, combine or cohere as a dynamic form that is always in the process of metamorphosis. if this concept of morphology is ontological, as I suggest it is, it nonetheless lacks a single centre, an essence, a simple unity; we might instead usefully think about its composition as an economy of differential relations. Secondly, morphology, as it is conceived here, is characterised by a tendency toward persistence and perseverance as much as mututation and transformation. To comprehend the question of forming and formation as an activity intrinsic to all bodies and things, I turn to Spinoza. In particular, his concept of conatus as the power of each thing to 'persevere in its being' (EIII, P6 ${ }^{\mathrm{iii}}$ ) helps 
draw out the political contours of this morphology, as well as to indicate some of the ways in which politics itself is always its mode of composition. To remain close to the tenor of Spinoza's radical philosophy of nature, I claim the conatus is best considered as a non-subjective principle, as an essential characteristic of all things, and that it is most usefully conceived beyond or outside the subject, in the wider context of an ontology of relation. This approach, however, will not elide the subject, and the intention here is to track its production amidst the morphological relations of which it is a part.

A number of contemporary theorists have been similarly drawn in recent years to the power of Spinoza's philosophy. Two theorists, in particular, stand out for consideration in the argument developed here since both share my regard for the way in which dominant philosophies of the subject must be unravelled and reconfigured, and both draw - albeit in quite different ways - upon Spinoza's concept of conatus. First, Jane Bennett's recent influential work Vibrant Matter theorises a new form of materialism where nature and life are dispersed processes and complexly constructed sites, and the agency of non-human assemblages is brought into play (Bennett, 2010, 2012). This attention to a non-human milieu of actants is attuned to its own resonances with Spinoza's philosophy. Suggesting that what she calls thing-power 'bears a family resemblance' to Spinoza's concept of conatus, Bennett seeks to dislodge the superiority of human power or agency $(2010$, p.2). At the same time, (and somewhat problematically for my own argument here), Bennett acknowledges that 'the otherwise important topic of subjectivity... gets short shrift' in her book, so she might focus instead 'on the task of developing a vocabulary and syntax for, and thus a better discernment of, the active powers issuing from non-subjects' (2010, p.ix, emphasis added). Second, Judith Butler's writings, expansive in their range and contribution, have often traced precisely the weight of a paradox intrinsic to the ontological formation of the human subject. For her, the subject describes a dual process where self-becoming, or selfformation, is inseparable from a subjugation to power. Subjection thus names a general trope, or retro-active turning of the subject back upon itself to delineate the very possibility of subjectivity (see Butler, 1997, chp 1). 'Part of the difficulty,' Butler reasons, 'is that the subject is itself a site of this ambivalence in which the subject emerges both as the effect of a prior power and as the condition of possibility for a radically conditioned form of agency' (1997, p.14-15). Neither constitutive nor constituted, and without the power of determination, that which Butler continues to call the subject must live out this paradox, or vacillation, at the heart of power relations. In her more recent writings, Butler recasts this already decomposed subject within the realm of ethics and responsibility where, following closely on Spinoza's trail, she posits 'a certain desire to persist', a force of conative striving 'that underwrites recognition, so that forms of recognition or, indeed, forms of judgement that seek to relinquish or destroy, the desire to persist, the desire for life itself undercut the very preconditions of recognition' (Butler, 2005, p.44). 
I do not wish to suggest that the positions of either Bennett or Butler be described as Spinozist in any straightforward sense. ${ }^{\text {iv }}$ Furthermore, the theoretical differences between the two are pronounced, even though at times the ethico-political resonances of their writings might share a common space. Their mobilisations of Spinoza are nonetheless significant; they point especially to the political stakes of, and the possible resources to be found within, and beyond, humanist discourses. Following an engagement with both theorists, I will conclude that neither position fully explores the potentialities inherent in Spinoza's thought, and specifically in relation to his concept of conatus. Ultimately, Butler's psychoanalytic formulations of the conatus as an a priori essence or desire tethers subjectivity too closely to a form of humanism, and opens her position to the kind of criticisms that my own reading of Spinoza hopes to avoid. Neither does Bennett's bracketing of what I call here 'the scene of subjectivity' end up able to bypass the matter of the subject. It may be the case, as the new materialist could argue, that the subject unravels to such a degree that theory can no longer lay hold of any subject. The risk of this position, in my view, is a repetition of the position of 'high' structuralism where the philosophical grammar of the subject emerges once again in another (possibly every) place: the world becomes subjectivised. This kind of position, this risk, must be avoided.

The distinctive morphology for thinking through subjectivity developed here remains sensitive to the dangers of continuing to work with, and utilise, the concept of the subject in a reconfigured sense. In my view, the matter of subjectivity is always a political matter. For this reason, I am reluctant to relinquish it. If it is the case that human subjects can no longer be understood to stand alone as the single principle or fulcrum of organisation for collective life, a stronger materialist account is required of the morphology of subjectivity, its coming into being as an arrangement of parts or as a temporary formation that might be subject to capture or combination, containment, exchange, and transformation. It is these political relations of figuration and mutation that my own engagement with Spinoza intends to develop. In my reading of it, the conatus becomes inextricably tied to the movement of power and force revealing, I suggest, something akin to the life of power upon the field of subjectivity. Against poststructuralist theories that all too readily missed the materialist component of analysis, reducing the subject to a symbolic, linguistic or discursive effect only to later resurrect, resignify and rearticulate a new human form, the concept of morphology brings a more nuanced, materialist understanding of the scene of subjectivity, bodies, and things, shedding light on political relations that might otherwise remain hidden.

My argument takes the following structure. I begin Part I with Spinoza's philosophy in order to elucidate the concept of the conatus at stake. Part II explores the different interpretations of Spinoza by Butler and Bennett. This allows me to set in play and 
delineate some of the requirements for my own morphology of subjectivity, which I set out further in Part III. Here I demonstrate the profound political sense of the concept of the conatus, and establish its utility in a morphological analysis of the scene of subjectivity.

\section{Thinking beyond the Subject with Spinoza: or, what exactly does Spinoza understand by the conatus?}

We find very few (in fact, only two) direct references to the subject in Spinoza's Ethics. ${ }^{v}$ This is in part because the subjectum, that which Foucault has theorised as the empiricotranscendental doublet of modern thought, had yet to crystallize and master the elements and relations governing its formation as the leitmotif of modern philosophy (see Foucault, 1970). There is, arguably, no grammatical ' $l$ ' in Spinoza's philosophy. But it is also because Spinoza's view of the world as substance requires no theory or faculty of consciousness and subjectivity as interiority, since its starting point precludes the kind of containment or identity that has generally accompanied such a theory. Spinoza's philosophy avoids the lure of anthropocentrism; his concern is with the production of an individuum (for which more than fifty references in the Ethics) conceived always as a composite of bodies and relations between parts, so that even the human body requires a wider body of organic and inorganic forms to maintain its existence. This premodern concept of individuum thus has nothing to do with liberal notions that we tend to associate with the bounded individual and possessive individualism. When in Part II of the Ethics Spinoza constructs an ontology of the production of complex bodies as an individuum (EIII, P13-14), it is apparent that their composition (and decomposition) is a dynamic and continuous process:

When a number of bodies, whether of the same or different size, are so constrained by other bodies that they lie upon one another, or if they so move, whether with the same degree or different degrees of speed, that they communicate their motions to each other in a certain fixed manner, we shall say that those bodies are united with one another and that they all together compose one body or Individual, which is distinguished from the others by this union of bodies (EII P13 Def)

Recent continental scholarship has drawn attention to the ideas of encounter and relation in the construction of Spinoza's ontology (Balibar, 1997, 1998; Deleuze, 1988a; Morfino, 2006). Building upon these approaches, I view Spinoza's ontology of substance not as the figure of a sub-stantia as ground, or foundation of all forms. All forms (better, morphologies) of life are modifications of an infinite, non-teleological substance that is best described as a field of variations or differences where each mode of substance, or genera of being, is constituted by relations of encounter and interaction with other 
modes (see Spinoza, Letter 32). Central to this dynamic ontology of becoming must be its intensive quality whereby bodies of all kinds (there is no clear distinction and necessary autonomy between human and non-human bodies) are constituted by degrees of power. To explore the dynamic form of a body's degree of power, Gilles Deleuze thinks of Spinoza's Ethics as a kind of ethology. 'Ethology', he writes, 'is first of all the study of the relations of speed and slowness, of the capacities for affecting and being affected that characterise each thing' (Deleuze, 1988a, p.125). Thus, we understand a body not in terms of its distinct properties, qualities, and functions but instead as a ratio of forces that are in turn composed of relations of speed, slowness, rest, agreement, and disagreement. This ethological rendering of the affective power of a body is highly important and influential, evidenced in the wide utility of Deleuze and Guattari's related concept of assemblage. For Spinoza, affect names a power to affect and be affected, thus making the body a site of transformation and production, but also ambivalence and vacillation (see Williams, 2010). The idea of morphology that I develop below must encompass Deleuze's Spinozist ethology of bodies, and it must be able to configure this intensive and extremely variable quality of affective power as one of its aspects. We can now begin to understand the desubjectifying effect of Spinoza's philosophy. Spinoza offers us the means to think the scene of subjectivity without reference to the metaphysical subject. In order to make sense of this paradoxical claim I turn now to trace in his philosophy the operations of an active, non-subjective conatus. This concept is arguably the key starting point for Spinoza's political theory. So, what exactly does Spinoza understand by the conatus?

\section{Spinoza and the Physics of Encounter}

For Spinoza, living organisms are distinguished from inorganic ones only by their degree of complexity and their capacity to establish more intensive levels of interaction with other things without sacrificing their composite power. All composite bodies or individuum have a tendency to maintain their consistency as a certain ratio or balance of physical integrity. Spinoza thus defines the active verb conatur as 'a body's natural tendency to move in a certain way' (PCP Part III Def). Conatus is the name for the power of each thing to 'persevere in its being' (E III, P6), to strive for improbable permanence and indefinite existence beyond the present. There is no necessary or exclusive relation between the conatus and the persistence of the human subject, and care must be taken not to anthropologize Spinoza's meaning of it. Indeed, in his early engagement with, and critique of Descartes, Spinoza makes clear that such a striving must be attached not simply to a thought, or a purely human endeavour, but to the boundless form of matter itself (PCP, Part III, Postulate). He is also explicit in his view that one must not distinguish between cause and effect, or the thing and its striving. Of those confused philosophers who continue to labour under such prejudices, (and anticipating Nietzsche's more frequently cited critique), Spinoza writes, 
...they distinguish between the thing itself and the striving that is in each thing to preserve its being, although they do not know what they understand by striving. For though the thing and its striving to preserve its being are distinguished by reason, or rather verbally (which deceives these people very greatly), they are not in any way really distinct (Spinoza, PCP Appendix, p.314).

It seems inadequate, therefore, to project upon Spinoza's nuanced understanding of the conatus a retrospective ontological account of human nature as self-movement and self- preservation. Nonetheless, it is through such a projection that some scholars begin to insert Spinoza's political philosophy into a social contract tradition (Feuer, 1987), a move that succeeds only partially because Spinoza's thought cannot wholly be contained within a state of nature argument (see also Balibar, 1998). Evidently, such a move also elides the ontology of encounter described above, as well as establishing the conatus as the kind of transcendental a priori category that Spinoza's philosophy always fought rigorously against (see El, Appendix).

Drawing on the terms of this arguably faulty humanist reading, a key discussion among some commentators has centred upon whether the conatus can be stretched to incorporate institutions as well as individuals. It seems illogical, they reason, to apply a psychological and individualist concept like the conatus to an institutional structure such as the state. ${ }^{\text {vi }}$ However, to argue on such grounds that the state cannot possess a conative - or for that matter a counter-conative - tendency is to ignore the differential relations of force and power that constitute the state as an institutional body forever in the making. Following the reasoning about the conatus developed here, the state may be understood as possessing a complex collective tendency to persevere in its own being. Whilst it might well be the case that in the Ethics Spinoza does mostly examine the conatus in its human situation as a form of desire, if we take into account the general claims of his ontology substantiated above, it becomes clear that the terms of such a debate appear to miss a vital point: the conatus principle is an essential characteristic of all things and is most usefully conceived outside the subject, in the wider context of an ontology of relation. But how might the striving of this nonsubjective conatus help us to understand the field of subjectivation?

Placed in the context of Spinoza's ontology of relation, conative striving may be described, with Spinoza, as the essence of a thing (EIII P7), but only if we underscore the way in which the metaphysical notion of a pure essence is challenged, or disrupted. The essence of a thing undergoes mutation and variation, and it is only in this sense that what Deleuze calls the elasticity of the conatus can be understood (Deleuze, 1990, 
p.222). There are no properties and functions of a body that do not rely on an elemental relationality. In the case of human being, Spinoza, like Hegel after him, locates the conatus in desire. But desire should not be read simply as a subjective automaton, impulse, or drive. This would be (once again) to humanise and essentialise Spinoza's thought, and to deprive the conatus of the relational reciprocities characterising the field of an infinitely variable nature, which Georges Canguilhem elegantly terms the 'poetic horizon' of natura naturans, and Foucault associate with power (Canguilhem, 1994, p.311; Foucault, 1990, p.92). Rather, the conatus is better understood as a field of forces whose inevitable existence is caught up in the dynamic play of conflictual relations. It is in and through this deeply political process that shapes of subjectivity are mobilised and take form. Indeed, perhaps the conatus is precisely this open series of power relations at the heart of every mode of existence: the power (of all things) to persist (and to desist, or resist); a configuration of forces that are internal and not prior to the conflict itself. Such a formulation places the conatus at the heart, at the centre, of power relations and secures an important element of a morphology of subjectivity without the metaphysical subject.

There is another aspect of this morphology that remains to be uncovered. In Part II of the Ethics, Spinoza proposes that 'the order and connection of ideas is the same as the order and connection between things' (EII P7). This brings to mind the conative force and political power of ideas in Spinoza's philosophy. Hasana Sharp (2011) has identified a tendency within studies of Spinoza's philosophy toward a one-sided account of bodies at the expense of ideas. Spinoza's nunaced materialism accords ideas their material weight; my own approach intends to avoid both a one-sided analysis that focuses only on bodies and things, as well as the critique, advanced most powerfully by Ruth Leys, that presents materialist theories of affective process as having almost nothing to say about the political realm of ideas, beliefs, and ideology (Leys, 2011, p.450-511, p.466). Implicating readings of Spinoza within her critique, Leys argues that the turn to affect has reinstated a dualism between mind and body, between the realms of rationality, cognition, and the representation of these as beliefs on the one hand, and affective, non-cognitive, non-representational states on the other. For Spinoza, these two attributes exist simultaneously in his ontology (where mind is thinking body, and ideas are dynamic activities imbued with affective resonance). Placing this alongside the highly influential position of Louis Althusser, who rediscovered in Spinoza the matrix of every possible theory of ideology, exposes the radical terms of Spinoza's philosophy (see Williams, 2013). Althusser's conception of ideology as an imaginary relation famously removed the agency of ideas from the human subject; these were not rejected but firmly embedded within material practices (Althusser, 1971). In this context, Sharp's strategy of renaturalisation is highly relevant since it helps draw attention to a powerful forcefield of ideas irreducible to the thinking subject as their author. Thus, ideas are living things that require 'revision, critique and pruning.' Ideas 'resist other ideas and endeavour to persevere and enhance themselves'; they are 'determined and dependent 
upon the forces and strivings of other ideas, just like the being of bodies' (Sharp, 2011, p74, p75, p76). Given the immense power of ideas to mobilise masses, to communicate and nourish the force of things, to capture and hold political elements and relations in place, the morphology developed here will underscore the conative force of ideas, signs and images as impersonal, non-subjective, autonomous conductors of power, affect, as well as being part of the scene of subjectivity itself. vii

In this first section, I have identified within Spinoza's dynamic philosophy the resources to develop a morphology to encompass the scene of subjectivity that does not rely on a philosophy of the subject. This analysis accentuates the mutual imbrication of ontology and politics, attends to the risks of anthropomorphism and humanist strains of politics, and theorises the conatus as a site of power and conflict. ${ }^{\text {viii }}$ Let us now consider the interpretations of Spinoza developed by Butler and Bennett. How do these distinctive turns to Spinoza develop his theory of conatus?

\section{Thinking through Spinoza's concept of conatus}

\section{Judith Butler: Desire for life, or life of power?}

Few commentators have addressed adequately Butler's enduring interest in Spinoza's philosophy, or the concept of conatus, which she claims 'remains at the core' of her work (2004, p.198, p.235-36). ${ }^{\text {ix }}$ These critics have tended to argue that the conatus and her Spinozism - introduce thick ontological categories that undermine the power of political critique in Butler's theory (Carver and Chambers, 2008, Chp 5, Lloyd, 2008; Chambers, 2004, White, 2000). These are certainly valid interpretations but they need pushing further, however, lest we reduce Spinoza's philosophy, together with the kinds of political critique opened up by it, to the very terms of Butler's own reading of him. Whilst Spinoza's thought is critical to the development of Butler's theory of power and subjectivity, it pulls her reading in three competing, arguably irreconcilable, directions. First, and most positively, It permits her to place Hegel and Foucault in fresh relief and read them anew through a Spinoza inflected lens (Butler, 1997, p.62). Second, and more controversially, it imbues Hegel's sense of life as an ethical struggle for recognition with a life drive attributable to Spinoza's ontology (Butler and Malabou, 2011, p.637). Third, and of greatest concern, Butler's reading pushes Spinoza directly towards Hegelian negativity and psychoanalysis. This complex mobilisation of Spinoza's philosophy is nonetheless compelling, as is the very specific utility of the concept of conatus developed by Butler. I have argued against understanding the conatus as an ontological capacity, an attribute of a subject, or an essentialist, pre-discursive desire. Drawing upon the morphological sense of the conatus sketched out above, and deconstructing Butler's reading of Spinoza's concept of the conatus, I query the limits of Butler's turn to Spinoza. To what degree might the political sense of a non-subjective conatus, described 
in Section 1 as inextricably tied to the movement of power and force, unravel the basis of Butler's construction of the subject?

In her book Giving An Account of Oneself (2005) originally given as the Spinoza Lectures at the University of Amsterdam in 2002, Butler approaches once more the problems addressed in her earlier work. After observing that The Psychic Life of Power perhaps accepted too readily the 'punitive scene of inauguration for the subject', which depends upon the internalization of the law and 'the causal tethering of the subject to the deed', Butler supplements her arguably Hegelian account of desire with what for her becomes a clear ethical injunction (2005, p.15). Following Spinoza, she posits 'a certain desire to persist', a force of conative striving 'that underwrites recognition, so that forms of recognition or, indeed, forms of judgement that seek to relinquish or destroy, the desire to persist, the desire for life itself undercut the very preconditions of recognition' (2005, p.44). In her careful engagement with Spinoza (2006; passim 2008; 2009), as well as in a co-authored essay with Catherine Malabou (2011), Butler endeavours to draw Hegel, Freud and Foucault in closer proximity to Spinoza's philosophy. As she had already observed in Psychic Life,

If desire has as its final aim the continuation of itself - and here one might link Hegel, Freud and Foucault all back to Spinoza's conatus - then the capacity of desire to be withdrawn and to reattach will constitute something like the vulnerability of every strategy of subjection (Butler, 1997, p.62, emphasis added).

With this formulation, Butler tethers the active, mobile, non-subjective insistence of the conatus to the capacity of a desire; a dynamic, dialectical logic of attachment and detachment that appears, at least, to absolve the subject from the paradox framing its inception and described in Psychic Life (1997, p.14-5). It is this paradox, whereby the subject is the vacillating scene of ambivalence, emerging both as effect of a prior power and as the condition of possibility for radical agency, that pushes the subject outside itself into the field of power relations, hence illuminating the scene of subjectivation. It is unsurprising that Butler turns to Spinoza to help her think the intimate reciprocity between power and psychic life. On Spinoza's reckoning it is, arguably, impossible to separate the dynamics of the conatus from relations of encounter that construct conceptions of life, conceptions of the human and the non-human, as well as normative patterns of existence. When Spinoza poses the well-known observation regarding our lack of knowledge about any body's capabilities (EIII P2), he recognises that whilst bodies may be subjected to asymmetric power relations, reified and held in bondage, they nonetheless present a disturbing form of power, or potentia, that is neither easily contained by, nor exchanged for a portion of political power. 
Rather than pushing further this productive political relation between an ineliminable power or force and the scene of subjectivation - perhaps also bringing Foucault and Spinoza closer together - Butler propels Spinoza and Hegel towards psychoanalysis, instead utilising the conatus to describe 'a desire that attaches to existence' that is 'presupposed by every act of the subject' (Butler, 2011, p.611, p.624, emphasis added). If Hegel's conception of desire owes something to Spinoza, Butler reasons, might not the 'the attribution of a life-drive to Hegel' help us understand the terms of ethical struggle in the Phenomenology of Spirit where "the "I" becomes redoubled, and ...bound up in a scene of desire and fear' (2011, p.637, p.629). This mapping of the psyche is taken further since Butler also identifies something akin to a death-drive in Spinoza. Thus, 'desiring life produces an ek-stasis in the midst of desire, a dependency on an externalization, something that is palpably not-me, without which no persistence is possible' (2006, p.113). It is this moment of negativity and decomposition of the subject that, for Butler, opens ethical life to the principle of human vulnerability (see Butler, 2004) This move is a provocative one; it highlights a particular way of reading Spinoza's conatus as a schema of life and death and propels Butler's politics into a kind of mortalist or corporeal humanism, where an emphasis upon existential vulnerability risks displacing a conflict-riven account of conatus, as well as undermining the Foucauldian tenor of her earlier arguments. ${ }^{x}$

My own reading of Spinoza's conatus as a non-subjective form has cautioned against its formulation as an a priori essence or drive somehow outside or before power-relations. It reveals, I have argued, not just a desire for life, but something akin to the life of power upon the field or scene of subjectivity. For many of her readers, it is the emphasis upon processes of subjection and subjectivation at the heart of power relations that is the most efficacious part of Butler's approach, and where, in my view, she might have had most to gain from her turn to Spinoza. Instead, the positing of a prediscursive conatus and a presocial subject situates Butler's analysis beyond critique and politics (see, also, Chambers, 2004, p.147; Braidotti, 2006; Lloyd 2008, p.101). Even allowing for the focus on human desire and Spinoza's account of how the power of a human body may be hindered by affects deriving from sadness, by objects and forces of which we have little understanding, there is very little within the Ethics to suggest a reading that limits the conatus to a 'human ontology' (Butler, 2006, p.116), or to a life (or death) drive as Butler proposes. Indeed, by drawing attention to the radical exposure of the conatus to events and encounters in the world that cannot be reduced to a single drive or cause, Spinoza unravels death and destruction, viewing them as reconfigurations or mutations of form. In short, Spinoza thinks the metamorphosis of a body (see EIV, Ax).

Ultimately, Butler presents Spinoza's concept of conatus within an overly narrow humanist ontology. She thus depoliticises Spinoza and fails to capture the critical force 
of the conatus as a non-subjective form, and hence also the political promise of Spinoza's philosophy for rethinking agency and the scene of subjectivity. In contrast, Bennett's appropriation of Spinoza is ontologically expansive and her attention to a nonhuman milieu of actants is attuned to its own resonances with his philosophy. To what extent might this vibrant materialism capture the dynamic scene of subjectivity?

\section{Jane Bennett: Lively matter and the absent scene of subjectivity}

It is primarily the agency of non-human assemblages that Jane Bennett's Vibrant Matter brings to the fore. Suggesting that what she calls thing-power bears a family resemblance' to Spinoza's concept of the conatus, Bennett seeks to dislodge the superiority of human power or agency (Bennett, 2010, p.2). Instead, Spinoza's 'conative substance turns itself into confederate bodies', and agency itself is best understood as a confederacy, or assemblage, of human and non-human elements (2010, p.22, p.23). In Vibrant Matter, and elsewhere, Bennett theorises a form of distributive agency where the myriad force of a range of actants is brought into play. In her example of an electrical power grid, this vital materialism envelops 'a volatile mix of coal, sweat, electromagnetic fields, computer programs, electron streams, profit motives, heat, lifestyles, nuclear fuel, plastic, fantasies of mastery, static, legislation, water, economic theory, wire and wood - to name just some of the actants' $(2010$, p.25). It is a cascade of different elements that mark the emergence of an event like an electricity blackout. Bennett characterises this assemblage of actants, or bodies, as a loose congregation or heterogeneous alliance. To complicate agency in this way, according to Bennett, is not to retreat from questions of political responsibility, but it does transform the locus of human agency and 'self-interest', both now distributed along a 'continuum of ontological types' (2010, p.37) where everything human co-mingles with an extended world of organic life. Indeed, despite Bennett's clear intention in the book to bracket the question of the human, and give the topic of subjectivity 'short shrift', her conception of vital materialism at the very least alludes, in my view, to a recasting of the scene, or locus, of subjectivity in keeping with the perspective developed here. In the final chapter of her book, Bennett notes that the subject itself is a kind of vibrant matter: it is 'its own outside' (2010, 116, my emphasis). What are we to understand by this most suggestive formulation and how might it relate to the political scene of subjectivity we have uncovered via Spinoza?

Rejecting the schema of inside/outside required by a philosophy of a subject demanding its own interiority and introspection, Bennett's analysis usefully unhinges the question of responsibility from a purely human intentionality. In clear contrast to Butler, for whom the untethering of the subject as source of moral agency becomes an indispensable basis for an ethics of the other, the ethico-political question of responsibility, for Bennett, becomes how to discern the presence of this often unruly, and aleatory, potentia of vibrant matter; how to reconceive the now outmoded form of 
(our) old moral maxims so that they might call out to, accommodate and express, the vibrant life of matter? In order to respond, Bennett initiates a reflexive conceptual gesture: she displaces the topic of subjectivity whilst at the same time recognising the peculiar power, and strategic value, of anthropomorphism to reveal the agency of unruly vitality (2010, p.120-122). Thus, 'It seems necessary and impossible to rewrite the default grammar of agency, a grammar that assigns activity to people and passivity to things' (2010, p.119). Bennett is acutely aware of the risks and twists of such a strategy. Refusing the 'futile attempt' to disentangle nature and culture, subject and object, the human and the non-human, she prefers instead to '...to engage more civilly, strategically, and subtly with the non-humans in the assemblages in which you, too, participate' (2010, p.116).

This attention to the paradox of the subject is commendable, but the ethical move attached to Bennett's approach is not without its difficulties since it risks leaving the human subject insufficiently deconstructed. It is not simply the displacement and postponement of the 'topics of human subjectivity, of the nature of human interiority, ...of what distinguishes the human from the animal, plant, and thing' $(2010$, p.120) that is troubling, but rather that the terms of engagement still appear to bypass the scene, the production, of subjectivity itself. Surely it is not so much the inhering of a subject within this heterogeneous force-field of nature as one actant amongst many, but rather the decomposition and dispersal of a distinctly human power as part of a wider morphology of relations that in turn transforms the subject. Conceived as 'its own outside' as Bennett puts it, the subject unravels and becomes something else: In my view, it is this scene that demands political analysis. Adrian Johnston has similarly argued that in overestimating the reciprocity between nature and subject such approaches 'risk squelching the subject altogether' (Johnston, 2012, 164). Other recent critics of new materialism have also identified a depoliticisation in a form of critique 'that seems to naturalize, if not normalize a vision of life forged only through collaboration, coordination and interdependence' (Washick and Wingrove, 2015, p.66; Hinton and Van der Tuin, 2014). This perceived focus upon reciprocity rather than struggle appears ironic given the proximity of Bennett's vital materialism to agonistic democracy with its attention to conflict and struggle (Bennett, 2006). Whilst the critiques of both Johnston and Washick and Wingrove are premised upon unhelpfully reductive views of the 'flat' ontologies entailed by new materialism (Johnston, for example, writes frequently of a Spinozist holism entirely out of place with the continentally inspired reading of him developed by my own reading), their observations about the fate of political critique nonetheless require careful consideration. I agree with Bennett that there exists an intimate connection between an immanent generativity, or creative praxis of matter and various figures of the human, but an account is required nonetheless of the genesis and the mobilisation of the subjective in the life of power. Without this, vital materialism holds in abeyance the rich political analysis entailed by a view of the conatus as a site of conflict and struggle, power and 
mobilisation.

In her response to Washick and Wingrove, Bennett goes some way towards a political analysis of these relations of power. She clarifies the ethico-political content of new materialism as including the attempt to 'reverse engineer' assemblages, (by discerning 'key operators' and parts most susceptible to transformation), and understanding how the parts of an assemblage work (Bennett, 2014, p.85). Furthermore, the ethical maxim of new materialism is not to be collapsed either into an extended Kantian categorical imperative or a Heideggerian call of Being. Rather, ethical responsiveness to 'things-inassemblage' has a distinctly practical aim: 'to find the best way to pursue my conatus while minimising the ill effects upon others and upon the whole eco-system on which everything depends' (Washick and Wingrove, 2014, p.72-74; Bennett, 2014, p.86). These suggestive remarks deserve amplification. But how are we to understand this uneasy reference to the conatus as a human property, and what might it mean to 'reverse engineer' an assemblage?

To think about how we might 'reverse-engineer' an assemblage, as Bennett suggests, requires, in my view, an account of a non-subjective conatus, as well as a morphological analysis that gives due weight to the presence of power and conflict. This permits an understanding of an assemblage as always already a form of capture of, and alignment between, bodies (which implies forms of exclusion and might include asymmetries rather than simply reciprocities and collaborations); we must ask which relations and what kind of mechanisms enable it to persist as this form, this scene, and no other? Are there relations of inequality, irregularity, between some elements that diminish or enhance their potentia? In particular, how might mutations in affect relate to the conative force of a complex individuum? Decoupling affect from human agency refocuses attention on the affective communication of ideas and images. These impersonal ideational forces are a necessary element of morphological analysis: ideas enable, mobilise and conduct forms of relation; whether these incite exclusions in the creation of forms of life and subjectivity, or act as transitive links that hold relations in place.

It is clear that Bennett's use of Spinoza is much more promising than Butler's for the argument developed here. We have seen how she presses the various modalities of materiality and agency much further than Butler's residual humanist position, where the principle of equal vulnerability becomes the touchstone for politics and ethics. Butler can never completely arrive at the materialist scene of subjectivity and remains tied in an anthropomorphic tangle of the kind Bennett hopes to break lose. However, Bennett's bracketing of the scene of subjectivity entails a displacement of the vital matter of the 
subject. I suggest the expansive ontology of vibrant materialism requires this kind of morphological analysis of the life of power upon the field of subjectivity. It is here that I think Spinoza's philosophy makes a significant contribution.

\section{Unravelling the subject: from metaphysical subject to individuum}

My own reading of Spinoza's philosophy clarifies how one can refer to the scene of (an unfinished) subjectivity without embracing an ontologically thick concept of the human subject, or becoming ensnared in forms of anthropomorphism. Most significantly, it allows me to place a dispersed notion of the subject into dialogue with new materialist accounts of the agency of things. Bestowing attention upon the scene of dispersal and remobilisation of subjectivity (albeit sometimes in/as another form) permits the political theorist to consider precisely how the conatus of this complex morphological form is mobilized, and gains both coherence and a strategic sense of conjunction amidst disparate parts in order to persist over time. In a recent study of contemporary French philosophy, lan James has observed elements of realignment away from linguistic paradigms and toward a focus upon the materiality of the real combined with a renewal of the subject (James, 2011). It is not simply a form of renewal that I am arguing for here, but it is worth being aware of the perceived need to continue to address the space of subjectivity within contemporary thought - however this may be theorised.

Let us very briefly revisit the key parts of the argument developed thus far. I have presented a concept of morphology as a heuristic device to map the dynamic activity of the conatus conceived as a field of forces through which relations between elements interact and take form. This idea of morphology is attuned with Spinoza's own geometric study of human actions, portrayed by him '...just as if it were a question of lines, planes and bodies' (E III, Pref). As a study of the form of things, morphology provides a conceptual mapping of the relations composing a particular form or individuum; it is a way of tracking their degree of complexity, magnitude, variation and, of course, their conative force and power. Being composed of a series of variable relations, an individuum maintains a degree of unity and coherence, or metastability when the elements composing it are held together by a specific ratio of forces (Balibar, 1997, p.22). The speed or intensity of encounters between bodies are prefigured by powerful concatenations of relations (be these power, intensity, or affect). Since the subject, as an unfinished form, comprises only one element amongst a collection of things upon which its 'own' existence and motion depends, I am similarly able to theorise this morphological scene of subjectivity (like any other thing) as dispersed, plural, mutative and malleable. I have argued, with Spinoza, that the conatus cannot be tied to the essence of a subject as desire because it is the striving to persevere of each thing (see EIII P7). The actual essence of any kind of thing must be tied to its elemental reality. This formulation frees the conatus from a subject-centred approach and disrupts 
the notion of essence (human or otherwise), which is now aligned with the power, action and interaction of any thing. This reading puts a creative dissonance to work upon concepts by considering the ways through which the concept of conatus traverses and unravels a concept of metaphysical subject. In this way, the conatus as this open series of power relations presents us with various (political) mutations of the life of power upon the field or scene of subjectivity.

This reading of Spinoza generates a powerful politics, especially when we combine this account of the individuum, with his reading, in the Political Treatise, of the metamorphosis of the collective force of the body from unruly crowd, or vulgas, to libera multitude. These are each forms of 'political subjectivity', but Spinoza recognised that the persistence and power of each depended wholly upon the relations composing them (TP, III and IV). We can certainly use this analysis today to investigate the persistence of political struggles, and their decomposition, over time (most influential here has been Hardt and Negri, 2001, 2005). Some political and social theorists have also begun to explore this collective composition of the individual, drawing upon the important concept of transindividualism, transported by Etienne Balibar from the ontogenetic philosophy of Gilbert Simondon to the fertile context of Spinoza's ontology (see Combes, 2013, Read, 2016). However, we might also reach beyond these recent explorations, insist upon an even wider understanding of individuation as a morphological process, and thereby entertain Spinoza's view of a Nature whose parts, or bodies, vary in an infinite number of ways, creating increasing degrees of complexity, and a greater power to interact with, and persist in a multiplicity of things (EII P13 L7 Schol).

In accordance with this latter view, I understand by politics any situation where there is a composition of powers acting. Forms of interaction have infinite possibilities but what makes their activity political is the setting in motion of a dynamic play of power relations, where relations and forces begin to take hold of the elements available. Politics, then, is literally the mode of composing a morphology of relations, of constructing a scene of subjectivity (perhaps by strategies of capture, combination, containment, compensation, exchange of parts, renewal, and transformation that indicate the life of power). How precisely these strategies take hold of relations, how they produce significant changes not just of degree but of kind, to paraphrase Donna Haraway (2015), and by what means they are mobilised (for example, the techniques through which they circulate and organise this scene), are precisely questions for politics.

How, then, does politics mobilise and combine the power and force of the conatus, as 
we have understood it here? To respond to this question, l'd like to enlist the recent work of Frederic Lordon (2014) and then finally reflect briefly upon the kind of contribution a morphological analysis can make to debates within contemporary political theory. I endorse Lordon's hypothesis in Willing Slaves of Capital: Spinoza and Marx on Desire that the conatus is at the root of every kind of servitude, and I applaud him for recognising the validity of Spinoza's thought, alongside that of Marx, for thinking about power. Lordon's approach exemplifies one kind of analysis, made possible by a well-developed Spinozist position, of the life of power upon the field of subjectivity, and I will utilise Lordon's discussion of the conatus to reflect further upon the political strategies of composition and formation enabled by my own study of morphology. Lordon's focus is 'the passionate complex of the employment relation' and the way in which these relations (from practices of empowerment, personal coaching and selfdevelopment at the workplace, to threats and sanctions emanating from the precarity of work) seek to capture 'the persistent heterogeneity of the conatus' viewed by him as a mobile energy or desire (without a clear object or goal) that 'sets bodies in motion' (Lordon, 2014, 29, 36). I have earlier questioned and rejected this narrow regard for desire in Butler's usage of Spinoza, but Lordon refuses this residual Hegelian position: if the conatus is our energy or desire, for him it is produced collaboratively, and '...owes everything to the interpellation of things' (2014, p.57, my emphasis). With this move outside the subject, or at least to one that, like Bennett, appears to recognise the power and participation of things, Lordon's analysis helps to explain how relations of power combine or hold a nominally dispersed or mutative subjectivity in a static position (of domination or servitude), whilst offering an example of how dispositions, habits and beliefs are a function of material practices. Conceiving the field of social conflict as a 'geometry of vectors', Lordon presents the struggle to capture the energy of the conatus as a strategic effort to create 'a continuous gradient of domination'. This analysis illustrates how contemporary neo-liberalism has sought to orient conatus vectors in a certain direction, to develop complete co-linearisation or coincidence. If such strategies of mobilisation were successful, we might expect the scene of subjectivity described here to all but disappear. Indeed, Lordon suggests that the conatus is always saturated or fully activated (2014, p.133-4). This attention to the immanence of power, (arguably in opposition to post-structuralist theories of resistance that require some reserve or lack from whence resistance moves), leads Lordon, in Spinozist fashion, to emphasise degrees of alignment and adjustment, where the angle of the vector can also give rise to produce a 'misalignment' or 'the clinamen of the individual conatus' (2014, 34- 36). This analysis enriches my own morphological analysis of mutations in the life of power whilst helping to shift attention outside the subject to understand the forces and causes that combine to create the scene of (neoliberal, for Lordon) subjectivity. This mapping of the conatus as a vector of power also gestures in the general direction of my own formulation of a non-subjective conatus although, ultimately, Lordon never embraces this kind of approach and confines his discussion to human/social relations. 
The theory of morphology developed here has endeavoured to stay close to the new materialist reading of Spinoza whilst making room for the scene of subjectivity. I have demonstrated how Spinoza's own avoidance of the lure of anthropocentrism helps make sense of the paradoxical idea of a subjectivity without the metaphysical subject reconfigured as part of an individuum. Utilising Spinoza's philosophy in a quite different way to Butler and Bennett, I have proposed the idea of a non-subjective conatus, and suggested that a morphological analysis of relations is the best way to understand its perseverance and transformation. My analysis endeavours to make sense of the unravelling of the subject and its persistence in other forms. It has detached the conatus from the narrow field of human desire, and focused attention upon the scene of subjectivity as folded into a wider, complex body whose relations exceed it and remain necessary for its continued existence. Subjectivity is thus composed of more than human aspects. At the same time, this morphological analysis returns a study of power to the discussion: the conatus is the power to persist but it is also a differential force and site of conflict.

These new observations bring sharply into focus some of the apparent fault lines within contemporary theory that have sometimes created unhelpful breaks or fractures between approaches, as seen in the various linguistic, discursive, materialist or biological turns of recent years. Adopting the kind of morphological analysis presented here, we might usefully revisit some of these fault lines in order to trace out important conceptual continuities, intersections, and affinities between these often opposed approaches. At the very least, by placing the spotlight on the scene of subjectivity, the contemporary political theorist might avoid the false antinomy between agency and structure, whilst continuing to track the production and composition of subjectivity in new political forms.

\section{Acknowledgements}

I would like to thank Lisa Disch, Filippo del Lucchese, Kim Hutchings, Sue Ruddick, Lasse Thomassen and the two anonymous readers of CPT for helpful discussions, suggestions, and reviews of earlier drafts of this article.

\section{Notes}

\footnotetext{
${ }^{\mathrm{i}}$ Freeden (1998) uses the idea of morphology in a different sense to describe ideology.
} 
ii Some readers might here recall the work of Paul Pierson (2000) on 'increasing returns'. He analyses the temporal patterns of stability and change within which forms of political organization unfold and persist as part of a dense network of major and minor historical and political factors.

iii All references to Spinoza's texts are taken from Curley's translation (Spinoza, 1985), unless otherwise stated, and use the following abbreviations: Ell (Part II of the Ethics); Dem (demonstration) P (proposition); Def (definition); Scol (scolium); Cor (corollary); L (Letter); PCP (Principles of Cartesian Philosophy).

iv Bennett's form of vital materialism draws Spinoza closer to the early materialism of Democritus, Lucretius, Epicurus, to Nietzsche, Diderot, Thoreau, Bergson, and further, to Deleuze, Latour, Varela, and others. Butler, in contrast, draws Spinoza close to Hegel and Adorno, to the phenomenology of MerleauPonty, and to her longstanding interest in psychoanalytic theory.

${ }^{v}$ Both references to the subject as subjectum in Spinoza's Ethics occur in relation to the first kind of (illusory) knowledge (see EIII p5; EV ax1).

vi For opposing views see Collier (2002) and Rice (1990). The terms of this debate repeat the antinomy between agency and structure, although Collier's nuanced argument certainly avoids this opposition.

vii For a discussion of imagination as such an impersonal conductor see Williams (2007).

viii I suggest this is a weak ontology since it provides only a frame, or set of conditions, for the political relations that ultimately mobilise it.

ix Hull (2012) and Sharp (2011) begin this kind of work but not in the direction developed here.

x See Honig (2010), Murphy (2011), and Braidotti (2006) for competing readings of Butler's humanist politics.

\section{References}

Althusser, Louis (1971), Essays on Ideology, London: New Left Books

Balibar, Etienne (1998), Spinoza and Politics Trans. P.Snowdon, Intro.W.Montag, London: Verso Books

Balibar, Etienne (1997), 'Spinoza: From Individuality to Transindividuality' Mededelingen vanwege het Spinozahauis Delft: Eburon

Bennett, Jane (2015), 'Ontology, Sensibility, Action' Contemporary Political Theory 14, 1, 82-89

Bennett, Jane (2010), Vibrant Matter: a political ecology of things, Durham and London: Duke University Press

Bennett, Jane (2006), 'In parliament with things' in Tonder, Lars and Lasse Thomassen eds. Radical Democracy: Between Abundance and Lack Manchester, UK: Manchester University Press

Braidotti, Rosi (2013) Posthumanism Cambridge: Polity Press

Braidotti, Rosi (2006) 'Affirmation versus Vulnerability : On Contemporary Ethical Debates' Symposium: Canadian Journal of Continental Philosophy 10,1, 235-54 
Butler, Judith (2006) 'The Desire to Live: Spinoza's Ethics Under Pressure' in V.Cahn, N.Saccamano, and D.Coli (eds) Politics and the Passions 1500-1850. Princeton, New Jersey: Princeton University Press.

Butler, Judith (2005), Giving An Account of Onself. New York, Fordham University Press.

Butler, Judith (2004) Undoing Gender New York and London: Routledge

Butler, Judith (1997), The Psychic Life of Power, Stanford: Stanford University Press

Butler, Judith and Malabou, Catherine (2011) 'You Be My Body For Me:Body, Shape, and Plasticity in Hegel's Phenomenology of Spirit', in Stephen Houlgate and Micheal Baur (eds) A Companion to Hegel Oxford: Blackwell

Canguilhem, Georges, (1994), A Vital Rationalist, New York: Zone Books Carver, Terrell and Chambers, Samuel, C (2008) Judith Butler and Political Theory: Toubling Politics

New York and London: Routledge

Chambers, Samuel, C (2004) Untimely Politics Edinburgh: Edinburgh University Press

Collier, Andrew (2002) 'The Materiality of Morals: Mind, Body and Interests in Spinoza's Ethics' in Segal, Gideon and Yovel, Yirmiyahau (eds) Spinoza, Burlington: Ashgate

Combes, Muriel (2013) Gibert Simondon and the Philosophy of the Transindividual trans. Thomas LaMarre Cambridge, Mass: The MIT Press

Deleuze Gilles (1990) Expressionism in Philosophy trans. Martin Joughin New York, NY: Zone Books

Deleuze Gilles (1988a) Spinoza: Practical Philosophy trans. R.Hurley San Francisco: City Lights Deleuze Gilles (1988b) Foucault trans. Sean Hand, Minneapolis: University of Minnesota Press Feuer Lewis (1987) Spinoza and the Rise of Liberalism Edison, NJ: Transaction Publishers Foucault, Michel (1970) The Order of Things, London, Tavistock

Foucault, Michel (1990) The History of Sexuality Volume 1: An Introduction trans. R. Hurley London: Penguin Books

Freeden, Michael (1996) Ideologies and Political Theory Oxford: Clarendon Press

Haraway, Donna (2015) 'Anthropocene, Capitalocene, Plantationocene, Chthulucene: Making Kin' Environmental Humanities 6, 159-165

Hardt, Michael and Negri, Antonio (2001) Commonwealth Cambridge, Mass: Harvard University Press Hardt, Michael and Negri, Antonio (2005) Multitude London: Penguin 
Honig, Bonnie (2010) 'Antigone's Two Laws: Greek Tragedy and the Politics of Humanism' New Literary History 41, 1-33

Hinton, Peta and Iris van der Tuin (2014) 'Preface' to Special issue 'Feminist Matters: The Politics of New Materialism' Women: A Cultural Review 25, 1, 1-8

Hull, Gordon (2012) 'Of Suicide and Falling Stones: Finitude, Contingency, and Corporeal Vulnerability in Judith Butler's Spinoza' in Hasana Sharp and Jason E. Smith (eds) Between Hegel and Spinoza: A Volume of Critical Essays London: Continuum

James, Ian (2012) The New French Philosophy Cambridge: Polity Press

Johnston, Adrian (2012) 'Think big: Toward a grand neuropolitics - or, Why I am not an immanent naturalist or vital materialist' in Frank Vander Val k(ed) Essays on Neuroscience and Political Theory: Thinking the Body Politic London and New York: Routledge

Leys, Ruth (2011) 'The Turn to Affect' Cultural Inquiry 37, 434-472

Lloyd, Moya (2007) Judith Butler: From Norms to Politics Clarendon: Polity

Lloyd, Moya (2008) 'Towards a cultural politics of vulnerability: precarious lives and ungrievable deaths' in Carver, T and Chambers, S (eds) Judith Butler's Precarious Politics: Critical Encounters London: Routledge

Morfino, Vittorio (2006) 'Spinoza: An Ontology of Relation' Graduate Faculty Philosophy Journal $27,1,103-127$

Murphy, Ann.V (2011) 'Corporeal Vulnerability and the New Humanism' Hypatia 26,3,575-590 21

Pierson, Paul (2000) Path Dependence, Increasing Returns, and the Study of Politics." 2000. American Political Science Review 94(2): 251-267

Read, Jason (2016) The politics of transindividuality Leiden, The Netherlands, Koninklijke Brill Rice, Lee (1990) 'Individual and Community in Spinoza's Social Psychology' in E. Curley and P.F.Moreau (eds) Spinoza: New Directions Leiden, E.J. Brill

Spinoza, Baruch de (1985) Collected Works of Spinoza Vol One E.Curley ed. and trans. Princeton N.J., Princeton University Press

Sharp, Hasana (2011) Spinoza and the Politics of Renaturalization Chicago: Chicago University Press

Washick, Bonnie and Wingrove, Elizabeth (2015) 'Politics that Matter: Thinking about power and justice with the new materialists' Contemporary Political Theory 14, 163-89

Williams, Caroline (2013) 'Althusser and Spinoza: the enigma of the subject' in Diefenbach, K, 
Farris, S, Gal, K, Thomas, P eds. Encountering Althusser: Politics and Materialism in Contemporary Radical Thought New York and London: Bloomsbury

Williams, Caroline (2010) 'Affective Processes without a subject: Rethinking the relation between subjectivity and affect with Spinoza' Subjectivity 3, 245-262

Williams, Caroline (2007) 'Thinking the Political in the Wake of Spinoza: Power, Affect and Imagination in the Ethics' Contemporary Political Theory 6, 349-369

White, Steven K. (2000) Sustaining Affirmation: The Strengths of Weak Ontology in Political Theory Princeton and Oxford: Princeton University Press

Wolfe, Cary (2010) What is Posthumanism? Minneapolis: Minnesota University Press 